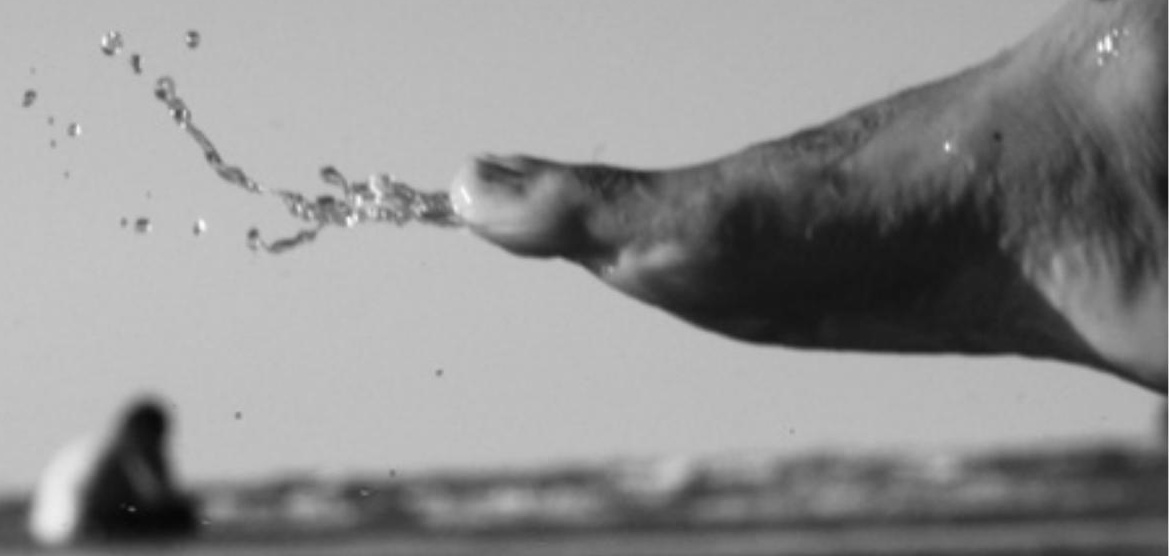

\title{
MATERIAL DE CÁTEDRA
}

REDEA. DERECHOS EN ACCIÓN | Año 2 NN$^{\circ} 4$ | Invierno 2017 PORTADA: SERGIO MICHAEL ÁLVAREZ | DE LAS MÁRGENES Y OTRAS ORILLAS. 


\section{El Ángel Del Descuido}

Cuando la noche se satura de madrugada, escucho alas golpeando contra un aire espeso y oscuro.

Ellas están en mí. Yo estoy en él, respirando miradas viscosas de almas condenadas a deambular durante siete años.

Habitamos la bóveda infinita como dos siameses decrépitos.

Se raspan las horas entre sí. Se desgrana en plumas el tiempo insensible. El de la crueldad. El de las mujeres que se desnucan contra el cordón de una vereda por malvender el último diente que les quedaba. El de los hombres que se pavonean con algodones debajo de la piel...

Aletean las horas.

Es el pájaro que todo lo ve.

Es el ángel del descuido.

Es el que me empapa en vinagre.

Es el que me clava el alfiler del alba entre dos costillas. 